\title{
Investigating the removal of some pharmaceutical compounds in hospital wastewater treatment plants operating in Saudi Arabia
}

\author{
Hamed Al Qarni ${ }^{1}$ • Philip Collier ${ }^{1}$ - Juliette O'Keeffe ${ }^{1}$. Joseph Akunna ${ }^{1}$ \\ Received: 11 September 2015 / Accepted: 29 February 2016/Published online: 21 March 2016 \\ (C) The Author(s) 2016. This article is published with open access at Springerlink.com
}

\begin{abstract}
The concentrations of 12 pharmaceutical compounds (atenolol, erythromycin, cyclophosphamide, paracetamol, bezafibrate, carbamazepine, ciprofloxacin, caffeine, clarithromycin, lidocaine, sulfamethoxazole and $\mathrm{N}$ acetylsulfamethoxazol (NACS)) were investigated in the influents and effluents of two hospital wastewater treatment plants (HWWTPs) in Saudi Arabia. The majority of the target analytes were detected in the influent samples apart from bezafibrate, cyclophosphamide, and erythromycin. Caffeine and paracetamol were detected in the influent at particularly high concentrations up to 75 and $12 \mathrm{ug} / \mathrm{L}$, respectively. High removal efficiencies of the pharmaceutical compounds were observed in both HWWTPs, with greater than $90 \%$ removal on average. Paracetamol, sulfamethoxazole, NACS, ciprofloxacin, and caffeine were eliminated by between $>95$ and $>99 \%$ on average. Atenolol, carbamazepine, and clarithromycin were eliminated by $>86 \%$ on average. Of particular interest were the high removal efficiencies of carbamazepine and antibiotics that were achieved by the HWWTPs; these compounds have been reported to be relatively recalcitrant to biological treatment and are generally only partially removed. Elevated temperatures and high levels of sunlight were considered to be the main factors that enhanced the removal of these compounds.
\end{abstract}

Responsible editor: Roland Kallenborn

Joseph Akunna

j.akunna@abertay.ac.uk

1 Urban Water Technology Centre, School of Science, Engineering and Technology, University of Abertay Dundee, Bell Street, Dundee DD1 1HG, Scotland, UK
Keywords Pharmaceutical compounds - Wastewater · Temperature $\cdot$ Removal rates $\cdot$ Saudi Arabia · Desert climate Activated sludge

\section{Introduction}

Pharmaceutical compounds include a wide range of chemicals with different structures, functions, behaviors, and activities and are used to enhance human health in the medical field. After their excretion by patients, these compounds and their metabolites can contaminate surface water, ground water, and drinking water (Kolpin et al. 2002; Monteiro and Boxall 2010; Li et al. 2013; Schaider et al. 2014). The main sources of these compounds and their metabolites in aquatic environments are wastewater treatment plants (but can also include sources such as manufacturing wastes and veterinary sources) (Vieno et al. 2007; Phillips et al. 2010; Vulliet et al. 2011; Tewari et al. 2013). Previous studies have detected high concentrations of some pharmaceuticals in hospital wastewaters (Ohlsen et al. 2003; Kosma et al. 2010; Kovalova et al. 2012). Hospital wastewater is, in most cases, connected directly to urban sewer systems without pretreatment, so municipal wastewaters are usually cotreated with hospital wastewater in municipal wastewater treatment plants (MWWTPs) (Alder et al. 2006); however, municipal systems are not usually designed to remove medical or pharmaceutical wastes.

Various methods for the removal of pharmaceuticals from wastewater have been studied such as conventional activated sludge (AS) (Oppenheimer et al. 2007; Nielsen et al. 2013) membrane bioreactors (MBRs) (Clara et al. 2005; Radjenović et al. 2009; Kim et al. 2014; Verlicchi et al. 2010; Kovalova et al. 2012), and moving bed biofilm reactors (MBBRs) (Escola Casas et al. 2015) as shown in Table 1 with regard to compounds analyzed in this study. Currently, the AS 
Table 1 Comparison of removal efficiencies of pharmaceutical compounds in various wastewater treatment processes for hospital wastewater (HWWTP) and municipal wastewater (MWWTP)

\begin{tabular}{|c|c|c|c|}
\hline Compound & Treatment plant type & Removal (\%) & Reference \\
\hline \multirow[t]{6}{*}{ Paracetamol } & HWWTP AS + disinfection (GR) & 75 & Kosma et al. (2010) \\
\hline & MWWTP AS + sand filter (GR) & 95.6 & Kosma et al. (2010) \\
\hline & MWWTP AS + trickling filter (UK) & 94 & Kasprzyk-Hordern et al. (2009) \\
\hline & MWWTP (+ industrial) AS (UK) & $>99$ & Kasprzyk-Hordern et al. (2009) \\
\hline & HWWTP MBR (pilot scale) (CH) & $>99$ & Kovalova et al. (2012) \\
\hline & HWWTP MBR (pilot scale) (ceramic UF) (DK) & $>99$ & Nielsen et al. (2013) \\
\hline \multirow[t]{11}{*}{ Carbamazepine } & HWWTP AS + disinfection (GR) & 30 & Kosma et al. (2010) \\
\hline & MWWTP AS + sand filter (GR) & NR & Kosma et al. (2010) \\
\hline & MWWTP (+ industrial) AS (ES) & NR & Radjenović et al. (2009) \\
\hline & MWWTP (+ industrial) MBR $^{\mathrm{c}}$ (pilot scale) (ES) & NR & Radjenović et al. (2009) \\
\hline & MWWTP (+ industrial) MBR $^{\mathrm{d}}$ (pilot scale) (ES) & NR & Radjenović et al. (2009) \\
\hline & HWWTP MBBR (pilot scale) (DK) & 10 & Escola Casas et al. (2015) \\
\hline & MWWTP AS + trickling filter (UK) & NR & Kasprzyk-Hordern et al. (2009) \\
\hline & MWWTP (+ industrial) AS (UK) & 13 & Kasprzyk-Hordern et al. (2009) \\
\hline & HWWTP MBR (pilot scale) (CH) & $-6 \pm 12$ & Kovalova et al. (2012) \\
\hline & HWWTP MBR (pilot scale) (ceramic UF) (DK) & 1 & Nielsen et al. (2013) \\
\hline & MWWTP MBR (hollow fiber membrane) & 28 & Kim et al. (2014) \\
\hline \multirow[t]{9}{*}{ Atenolol } & MWWTP (+ industrial) AS (ES) & $61.2 \pm 18.6$ & Radjenović et al. (2009) \\
\hline & MWWTP (+ industrial) MBR $^{\mathrm{c}}$ (pilot scale) (ES) & $76.7 \pm 12.6$ & Radjenović et al. (2009) \\
\hline & MWWTP (+ industrial) MBR $^{\mathrm{d}}$ (pilot scale) (ES) & $69.5 \pm 12.5$ & Radjenović et al. (2009) \\
\hline & HWWTP MBBR (pilot scale) (DK) & 40 & Escola Casas et al. (2015) \\
\hline & MWWTP AS + trickling filter (UK) & 78 & Kasprzyk-Hordern et al. (2009) \\
\hline & MWWTP (+ industrial) AS (UK) & 85 & Kasprzyk-Hordern et al. (2009) \\
\hline & HWWTP MBR (pilot scale) (CH) & $99 \pm 1$ & Kovalova et al. (2012) \\
\hline & HWWTP MBR (pilot scale) (ceramic UF) (DK) & 70 & Nielsen et al. (2013) \\
\hline & MWWTP MBR (hollow fiber membrane) (CAN) & 77 & Kim et al. (2014) \\
\hline \multirow[t]{6}{*}{ Bezafibrate } & MWWTP (+ industrial) AS (ES) & $80.8 \pm 20.9$ & Radjenović et al. (2009) \\
\hline & MWWTP (+ industrial) MBR ${ }^{\mathrm{c}}$ (pilot scale) (ES) & $90.3 \pm 10.1$ & Radjenović et al. (2009) \\
\hline & MWWTP (+ industrial) MBR ${ }^{\mathrm{d}}$ (pilot scale) (ES) & $88.2 \pm 15.3$ & Radjenović et al. (2009) \\
\hline & MWWTP AS + trickling filter (UK) & 45 & Kasprzyk-Hordern et al. (2009) \\
\hline & MWWTP (+ industrial) AS (UK) & 71 & Kasprzyk-Hordern et al. (2009) \\
\hline & HWWTP MBR (pilot scale) (CH) & $>91$ & Kovalova et al. (2012) \\
\hline Lidocaine & HWWTP MBR (pilot scale) (CH) & $56 \pm 13$ & Kovalova et al. (2012) \\
\hline \multirow[t]{3}{*}{ Ciprofloxacin } & HWWTP MBR (pilot scale) (CH) & $51 \pm 13$ & Kovalova et al. (2012) \\
\hline & HWWTP MBR (pilot scale) (ceramic UF) (DK) & 36 & Nielsen et al. (2013) \\
\hline & MWWTP MBR (hollow fiber membrane) (CAN) & 89 & Kim et al. (2014) \\
\hline \multirow[t]{9}{*}{ Clarithromycin } & HWWTP MBR (pilot scale) (CH) & $50 \pm 12$ & Kovalova et al. (2012) \\
\hline & MWWTP AS + UV (TW) & NR & Lin et al. (2010) \\
\hline & MWWTP AS + chlorination (TW) & NR & Lin et al. (2010) \\
\hline & MWWTP AS + chlorination (TW) & 10 & Lin et al. (2010) \\
\hline & MWWTP AS + sand filer (TW) & NR & Lin et al. (2010) \\
\hline & MWWTP trickling filter + chlorination (TW) & 99 & Lin et al. (2010) \\
\hline & MWWTP AS + chlorination (TW) & NR & Lin et al. (2010) \\
\hline & HWWTP MBR (pilot scale) (ceramic UF) (DK) & 64 & Nielsen et al. (2013) \\
\hline & MWWTP MBR (hollow fiber membrane) (CAN) & NR & Kim et al. (2014) \\
\hline Sulfamethoxazole & MWWTP (+ industrial) AS (ES) & $73.8 \pm 12.7$ & Radjenović et al. (2009) \\
\hline
\end{tabular}


Table 1 (continued)

\begin{tabular}{|c|c|c|c|}
\hline Compound & Treatment plant type & Removal (\%) & Reference \\
\hline & MWWTP (+ industrial) MBR ${ }^{\mathrm{c}}$ (pilot scale) (ES) & $80.8 \pm 12.2$ & Radjenović et al. (2009) \\
\hline & MWWTP (+ industrial) MBR ${ }^{\mathrm{d}}$ (pilot scale) (ES) & $78.3 \pm 13.9$ & Radjenović et al. (2009) \\
\hline & HWWTP MBBR (pilot scale) (DK) & NR & Escola Casas et al. (2015) \\
\hline & MWWTP AS + trickling filter (UK) & 66 & Kasprzyk-Hordern et al. (2009) \\
\hline & MWWTP (+ industrial) AS (UK) & 83 & Kasprzyk-Hordern et al. (2009) \\
\hline & HWWTP MBR (pilot scale) (CH) & $7 \pm 57$ & Kovalova et al. (2012) \\
\hline & MWWTP AS + UV (TW) & 42 & Lin et al. (2010) \\
\hline & MWWTP AS + chlorination (TW) & 20 & Lin et al. (2010) \\
\hline & MWWTP AS + chlorination (TW) & 59 & Lin et al. (2010) \\
\hline & MWWTP AS + sand filter (TW) & 88 & Lin et al. (2010) \\
\hline & MWWTP trickling filter + chlorination (TW) & 45 & Lin et al. (2010) \\
\hline & MWWTP AS + chlorination (TW) & 26 & Lin et al. (2010) \\
\hline & HWWTP MBR (pilot scale) (ceramic UF) (DK) & 97 & Nielsen et al. (2013) \\
\hline & MWWTP MBR (hollow fiber membrane) (CAN) & 66 & Kim et al. (2014) \\
\hline \multirow[t]{15}{*}{ Erythromycin } & MWWTP (+ industrial) AS (ES) & $35.4 \pm 50.5$ & Radjenović et al. (2009) \\
\hline & MWWTP (+ industrial) MBR ${ }^{\mathrm{c}}$ (pilot scale) (ES) & $43.0 \pm 51.5$ & Radjenović et al. (2009) \\
\hline & MWWTP (+ industrial) MBR $^{\text {d }}$ (pilot scale) (ES) & $25.2 \pm 108.9$ & Radjenović et al. (2009) \\
\hline & HWWTP MBBR (pilot scale) (DK) & $<20$ & Escola Casas et al. (2015) \\
\hline & MWWTP AS + trickling filter $\left(\mathrm{UK}^{\mathrm{a}}\right)$ & 14 & Kasprzyk-Hordern et al. (2009) \\
\hline & MWWTP (+ industrial) AS (UKª) & 72 & Kasprzyk-Hordern et al. (2009) \\
\hline & HWWTP MBR (pilot scale) $\left(\mathrm{CH}^{\mathrm{b}}\right)$ & $<60$ & Kovalova et al. (2012) \\
\hline & MWWTP AS + UV $\left(\mathrm{TW}^{\mathrm{a}}\right)$ & NR & Lin et al. (2010) \\
\hline & MWWTP AS + chlorination $\left(\mathrm{TW}^{\mathrm{a}}\right)$ & NR & Lin et al. (2010) \\
\hline & MWWTP AS + chlorination $\left(\mathrm{TW}^{\mathrm{a}}\right)$ & 77 & Lin et al. (2010) \\
\hline & MWWTP AS + sand filter $\left(\mathrm{TW}^{\mathrm{a}}\right)$ & NR & Lin et al. (2010) \\
\hline & MWWTP trickling filter + chlorination $\left(\mathrm{TW}^{\mathrm{a}}\right)$ & 56 & Lin et al. (2010) \\
\hline & MWWTP AS + chlorination $\left(\mathrm{TW}^{\mathrm{a}}\right)$ & NR & Lin et al. (2010) \\
\hline & HWWTP MBR (pilot scale) (ceramic UF) (DK) & 37 & Nielsen et al. (2013) \\
\hline & MWWTP MBR (hollow fiber membrane) $\left(\mathrm{CAN}^{\mathrm{a}}\right)$ & 12 & Kim et al. (2014) \\
\hline \multirow[t]{2}{*}{ Cyclophosphamide } & HWWTP MBR (pilot scale) (CH) & $<20$ & Kovalova et al. (2012) \\
\hline & HWWTP MBR (pilot scale) (ceramic UF) (DK) & 12 & Nielsen et al. (2013) \\
\hline \multirow[t]{9}{*}{ Caffeine } & HWWTP AS + disinfection (GR) & 75 & Kosma et al. (2010) \\
\hline & MWWTP AS + sand filter (GR) & 89 & Kosma et al. (2010) \\
\hline & MWWTP AS + UV (TW) & 99 & Lin et al. (2010) \\
\hline & MWWTP AS + chlorination (TW) & $>99$ & Lin et al. (2010) \\
\hline & MWWTP AS + chlorination (TW) & 97 & Lin et al. (2010) \\
\hline & MWWTP AS + sand filter (TW) & 99 & Lin et al. (2010) \\
\hline & MWWTP trickling filter + chlorination (TW) & 96 & Lin et al. (2010) \\
\hline & MWWTP AS + chlorination (TW) & $>99$ & Lin et al. (2010) \\
\hline & MWWTP MBR (hollow fiber membrane) (CAN) & 100 & Kim et al. (2014) \\
\hline
\end{tabular}

$A S$ activated sludge, $M B R$ membrane bioreactor, $M B B R$ moving bed biofilm reactor, $U F$ ultrafiltration, $N R$ no removal, $C A N C$ Canada, $C H$ Switzerland, $D K$ Denmark, ES Spain, GR Greece, TW Taiwan, UK United Kingdom

${ }^{\text {a }}$ Erythromycin $\cdot \mathrm{H}_{2} \mathrm{O}$

${ }^{\mathrm{b}}$ Erythromycin + Eryt $\cdot \mathrm{H}_{2} \mathrm{O}(30-100 \%)$

${ }^{\mathrm{c}}$ Flat sheet microfiltration

${ }^{\mathrm{d}}$ Hollow fiber UF 
process is the most common treatment process employed at wastewater treatment plants; previous studies have indicated a significant variation in the removal of pharmaceutical compounds during treatment using the AS process, ranging from complete removal (e.g., paracetamol and ibuprofen) to poor removal (e.g., carbamazepine). Differences between removal rates from various processes have also been studied. No significant differences in the removal efficiency of certain compounds (e.g., ibuprofen, triclosan, and caffeine) were found between the MBR and conventional AS processes by Oppenheimer et al. (2007). Pilot and laboratory-scale experiments by Nielsen et al. (2013) found that removal of many active pharmaceutical ingredients could be effectively achieved using MBR plus ozone, ozone + hydrogen peroxide or powdered activated carbon (PAC), with MBR + PAC being the most efficient technology. MBBRs were found to be a potentially promising solution for treatment of hospital wastewater, with high elimination rates ( $>80 \%)$ observed for some compounds (ibuprofen, propranolol, acetyl-sulfadiazine) in batch experiments, however, with low elimination rates $(<20 \%)$ observed for others (sulfamethoxazole, venlafaxine, iopromide, tramadol, and diatrizoic) (Escola Casas et al. 2015).

Some studies have also investigated the biodegradation efficiency of some pharmaceutical compounds under anaerobic processes (Carballa et al. 2007; Musson et al. 2010). The reported biodegradation efficiency has varied from no elimination to high elimination. For example, Carballa et al. (2007) observed significant elimination rates for some antibiotics (sulfamethoxazole) and natural estrogens, while there was no elimination of carbamazepine. Musson et al. (2010) investigated the fate of six pharmaceutical compounds $(17 \alpha-$ ethynylestradiol, acetaminophen, acetylsalicylic acid, ibuprofen, metoprolol tartrate, and progesterone) during anaerobic digestion and only found a significant biodegradation potential for acetylsalicylic acid.

The level of removal efficiency by biological treatments depends on the physicochemical properties of the compounds, the type of wastewater treatment technology, the hydraulic retention time (HRT), the solids retention time (SRT), and the climatic conditions (e.g., dilution, rainfall, temperature, and level of sunlight) (Kasprzyk-Hordern et al. 2009; McAdam et al. 2010; Sahar et al. 2011). The variation mainly occurs because these parameters, and other physicochemical properties of compounds, affect microbial activity and growth, thereby resulting in a change in effluent quality (Pollice et al. 2002; Fernandez-Fontaina et al. 2012; Arévalo et al. 2014; Chen et al. 2014).

Temperature conditions in biological wastewater treatment processes can significantly affect microbial activity and growth (LaPara et al. 2000; Vieno et al. 2005; Massmann et al. 2006; Calderón et al. 2012). Previous studies in this field have only investigated the removal efficiency of pharmaceutical compounds in AS in response to seasonal variations in temperature in Europe and North America (average $<20{ }^{\circ} \mathrm{C}$ ). Relatively low removal efficiencies have been observed, especially during the winter period (Heberer 2002; Kolpin et al. 2002; Metcalfe et al. 2003; Miao et al. 2005). However, temperature stability in the biological wastewater treatment processes may be an important factor in micropollutant removal, particularly in arid and semiarid areas, where the average annual temperature is $>25^{\circ} \mathrm{C}$. In arid and semiarid areas, such as Saudi Arabia, the diurnal temperature during summer can range between 30 and $55^{\circ} \mathrm{C}$, with an annual average of above $30^{\circ} \mathrm{C}$ (Aksakal and Rehman 1999; Qadir et al. 2010; Almazroui et al. 2014). This will consequentially result in higher temperatures in wastewaters compared to both winter and summer conditions in temperate countries. In addition to temperature, scarcity of available rainfall and intense sunlight can affect removal efficiency (Hai et al. 2011). This study aims to investigate the occurrence and fate of selected pharmaceutical compounds at onsite hospital wastewater treatment plants (HWWTPs) in Riyadh (Saudi Arabia) operating under high ambient temperature conditions.

\section{Materials and methods}

\section{Treatment plant selection}

Two HWWTPs were selected in central Saudi Arabia, both of which were located in Riyadh. The choice of these locations was based on the following factors: (i) the HWWTPs performed onsite treatment; and (ii) the HWWTPs at both hospitals employed AS processes. As far as was known, all other HWWTPs in Riyadh (in fact, the entire country) employed AS processes; therefore, the sites selected in this study should generally be representative of HWWTPs in Saudi Arabia. The known operational parameters at the two HWWTPs are described in Table 2. For the purposes of this study, the sample collection locations are referred to as sites HWWTP1 and HWWTP2. Due to limited access to data, some information on the operational processes at the HWWTPs was not available (e.g., the HRT and SRT, among other operational parameters that are commonly measured). The wastewater at each hospital consists of a similar combination of units including outpatients, inpatients, medical units, restaurants, and laundry, with the only difference being the absence of a urology unit at HWWTP2.

\section{Sampling}

Figure 1 summarizes the treatment processes used at each plant. Samples were collected from the influent (before the secondary treatment) and effluent (after the tertiary treatment) of each HWWTP. Sampling was carried out twice weekly for 
4 weeks in April 2014. One sample of influent and one sample of effluent were collected on each sampling day. Samples were collected in the middle of the day (between 11:00 and 14:00) when the air temperature was at its highest $\left(30-35^{\circ} \mathrm{C}\right)$. The samples were collected by grab sampling in $1000-\mathrm{mL}$ sterile plastic bottles (Saudi Water, Saudi Arabia) and transferred to the laboratory in a cool box, and then frozen at $-20{ }^{\circ} \mathrm{C}$. All the samples collected from each respective sampling point (influent and effluent) $(8 \times 1000 \mathrm{ml}$ each $)$ were mixed together to provide a composite sample for the sampling period. Three aliquots of $1000 \mathrm{~mL}$ of the mixed samples for each site were then taken for analysis. This allowed an assessment of the levels of pharmaceutical compounds present in the influents and effluents of the HWWTPs in the middle of the day, which likely represented the highest daily water temperatures and the maximum loads received by the HWWTPs (Ort et al. 2010).

\section{Analysis of pharmaceutical compounds}

The pharmaceutical compounds investigated in this study were representative of the wide range of pharmaceutical compounds commonly present in municipal wastewaters (Yu et al. 2006; Lin et al. 2010; Helwig et al. 2013). These compounds included antibiotics, analgesics, $\beta$-blockers, anesthetics, anticonvulsants, cytostatic antineoplastics, and lipid regulators. Caffeine concentrations were also analyzed. Sample analysis was carried out by an external laboratory (School of Engineering and Built Environment, Glasgow Caledonian University, United Kingdom).

\section{Sample preparation}

The pharmaceutical compounds were extracted using solid phase extraction (SPE). The triplicate subsamples $(1000 \mathrm{~mL})$ from each of the sampling points were filtered sequentially

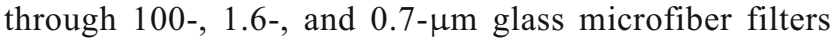
(Whatman, UK), and then through a $0.45-\mu \mathrm{m}$ cellulose nitrate membrane sterile filter (Whatman, UK). Each filtered sample was adjusted to $\mathrm{pH} 2.0( \pm 0.1)$ with the addition of $0.5 \mathrm{M}$ hydrochloric acid. Prior to extraction, the Strata-X (1-g/ 20-mL, $33 \mu$ polymeric reversed-phase) cartridges (Phenomenex, UK) were preconditioned with $2 \mathrm{~mL}$ of methanol and $2 \mathrm{~mL}$ of distilled water. Subsequently, the samples were loaded at a flow rate of $10 \mathrm{~mL} / \mathrm{min}$ using an SPE vacuum manifold with 12 accessories (Macherey-Nagel, Germany). The cartridges were dried under a vacuum. After extraction, the cartridges were washed with $3 \times 2-\mathrm{mL}$ water $(18 \mathrm{M} \Omega \mathrm{cm})$ and then eluted with $4 \times 2-\mathrm{mL} \mathrm{CH}_{3} \mathrm{CN} / \mathrm{MeOH}$ containing $0.1 \%$ formic acid. The samples were then dried under nitrogen gas. The dried samples were reconstituted into $\mathrm{CH}_{3} \mathrm{CN} /$ $\mathrm{H}_{2} \mathrm{O}(30 / 70)$. The samples were then diluted further $(1: 8)$ by $100-\mu \mathrm{L}$ aliquot and adding $700 \mu \mathrm{L}$ of $\mathrm{CH}_{3} \mathrm{CN} / \mathrm{H}_{2} \mathrm{O}$. The dilution of samples helped to minimize matrix effects; however, this was not completely eliminated. Acetonitrile used was Optima grade (Fisher). Deuterated internal standards were added to afford a concentration of $5 \mu \mathrm{g} / \mathrm{L}$ prior to liquid chromatography/tandem mass spectrometry (LC-MS/MS) analysis. Deuterated internal standards used were atenolol (d7), carbamazepine (d8), lidocaine (d10), paracetamol (d3), and caffeine (d3), purchased from CDN isotopes. Pharmaceutical standards used were Sigma-Aldrich HPLC standard grade.

\section{LC-MS/MS analysis}

Each composite sample was analyzed in triplicate. Chromatographic separation of the analytes was performed using LC-MS/MS (Thermo Scientific Q Exactive Quadrupole-Orbitrap Mass Spectrometer) equipped with a column: Waters Xselect HSS T3. $2.1 \times 150 \mathrm{~mm}$ (Water, UK). The MS positive ion mode and experiment type are listed in Table 3 along with linear range, retention times, and limits of quantification (LOQs). The samples were bracketed by calibration line and quality control standards (calibration line criteria of $\pm 20 \%$ linear calibration with a weight of $1 / x^{2}$ ). Conditions included electrospray ionization, positive ion mode, full scan range of 100-1000, mass resolution of 17,500, targeted MS2 mass resolution of 17,500, spray voltage of $3.5 \mathrm{kV}$, capillary temperature of $300^{\circ} \mathrm{C}$, and auxiliary gas heater of $300^{\circ} \mathrm{C}$. Some compounds were analyzed in MS2, while those that fragmented less well were analyzed in full scan mode.

\section{Results and discussion}

\section{Occurrence of pharmaceutical compounds in hospital wastewater}

Out of the 12 compounds analyzed, 9 pharmaceutical compounds were detected, including 3 antibiotic compounds (ciprofloxacin, clarithromycin, sulfamethoxazole) and the antibiotic metabolite, NACS, one analgesic (paracetamol), one stimulant (caffeine), one $\beta$-blocker (atenolol), one anesthetic (lidocaine), and one anticonvulsant (carbamazepine). The other compounds tested for, including bezafibrate, erythromycin, and cyclophosphamide were not detected in either the influents or effluents of the HWWTPs. Mean concentrations are presented in Table 4. Removal efficiencies were calculated as difference between mean concentrations in influent and effluent.

Caffeine and paracetamol were detected in all of the influent samples and were present at the highest concentrations of all the compounds analyzed, up to 7479 and $12,390 \mathrm{ng} / \mathrm{L}$, respectively. Especially high concentrations of caffeine 
Table 2 Overview of the operational parameters at the two hospital wastewater treatment plants studied

\begin{tabular}{|c|c|c|c|c|}
\hline Parameters & \multicolumn{2}{|c|}{ HWWTP1 } & \multicolumn{2}{|c|}{ HWWTP2 } \\
\hline Number of beds & \multicolumn{2}{|l|}{300} & \multicolumn{2}{|l|}{215} \\
\hline Annual wastewater volume $\left(\mathrm{m}^{3}\right)$ & \multicolumn{2}{|l|}{330,000} & \multicolumn{2}{|l|}{227,000} \\
\hline Process technology & \multicolumn{2}{|l|}{ Aerobic } & \multicolumn{2}{|l|}{ Aerobic } \\
\hline Ambient $\left({ }^{\circ} \mathrm{C}\right)$ & \multicolumn{2}{|l|}{$28 \pm 7$} & \multicolumn{2}{|l|}{$28 \pm 7$} \\
\hline \multirow[t]{2}{*}{$\mathrm{pH}$} & \multicolumn{2}{|l|}{$7.0-7.5$} & \multicolumn{2}{|l|}{$6.8-7.5$} \\
\hline & Influent & Effluent & Influent & Effluent \\
\hline COD (mg/L) & 376 & 64 & 336 & 27 \\
\hline $\mathrm{NH}_{4}^{+}(\mathrm{mg} / \mathrm{L})$ & 22.3 & 0.3 & 19.0 & 0 \\
\hline $\mathrm{NO}_{2}{ }^{-}(\mathrm{mg} / \mathrm{L})$ & 0.3 & 0.6 & 0.3 & 0.3 \\
\hline $\mathrm{NO}_{3}{ }^{-}(\mathrm{mg} / \mathrm{L})$ & 0.2 & 0.7 & 0.4 & 2.4 \\
\hline
\end{tabular}

$(>90 \mu \mathrm{g} / \mathrm{L})$ were found at the HWWTP1 influent. Caffeine has been detected in MWWTPs in China at concentrations at 3.4-6.6 $\mu \mathrm{g} / \mathrm{L}$ (Sui et al. 2010), in Switzerland at 7-73 $\mu \mathrm{g} / \mathrm{L}$ (Buerge et al. 2003), and in Spain at concentrations up to $89 \mu \mathrm{g} / \mathrm{L}$ (Martín et al. 2012). Alidina et al. (2014) reported high concentrations of caffeine $(64-16,500 \mathrm{ng} / \mathrm{L})$ in the effluent of six Saudi MWWTPs (but no data were available for influent concentrations in their study). The high concentrations of caffeine observed in this study may be related to its administration in combination with other medication in order to enhance the effects of certain analgesics in cough, cold, and headache medicines (Lin et al. 2010; Weigel et al. 2002). It is also used as a cardiac, cerebral, and respiratory stimulant and as a diuretic (Buerge et al. 2003). Both caffeine and paracetamol were almost completely removed during the treatment process in both of the HWWTPs. Negligible concentrations of paracetamol were detected in the both HWWTP effluents, while the removal efficiencies for caffeine were near $100 \%$.

As expected, the hospital influents were found to contain high levels of antibiotics and three of the antibiotic compounds examined (ciprofloxacin, clarithromycin, sulfamethoxazole) and the sulfamethoxazole metabolite, NACS, were detected at concentrations ranging from 30 to $5611 \mathrm{ng} / \mathrm{L}$ in the influents of the HWWTPs. The high concentrations of the antibiotics in the raw hospital wastewater are likely to be present due to the high levels of antibiotic consumption in hospitals (Kümmerer 2009). Ciprofloxacin was present in both influents at the highest concentrations of the antibiotic compounds tested, followed by NACS at concentrations up to 5611 and $1234 \mathrm{ng} / \mathrm{L}$, respectively. Relatively low concentrations $(<160 \mathrm{ng} / \mathrm{L})$ of sulfamethoxazole and clarithromycin were detected in the raw hospital wastewater. Previous studies have also found high concentrations of sulfamethoxazole $(730 \mathrm{ng} / \mathrm{L})$ in Saudi effluents from MWWTPs (Alidina et al. 2014). In this study, the concentrations of all the antibiotics in the effluents of the HWWTPs were found to be negligible and lower than their respective predicted no effect concentrations (PNECs) reported in the literature of $9.38 \times 10^{5} \mathrm{ng} / \mathrm{L}$ for ciprofloxacin, $70 \mathrm{ng} / \mathrm{L}$ for clarithromycin, and $27 \mathrm{ng} / \mathrm{L}$ for sulfamethoxazole (Verlicchi et al. 2012).

Carbamazepine, atenolol, and lidocaine were consistently detected in the influent samples of the HWWTPs at relatively low concentrations $(<1 \mu \mathrm{g} / \mathrm{L})$. Previously, atenolol was detected at low concentrations $(1-4 \mathrm{ng} / \mathrm{L})$ in the influent of a Saudi MWWTP (Shraim et al. 2012). These drugs have been considered relatively recalcitrant to biological treatment and are generally only partially removed in wastewater treatment systems (Zhang et al. 2008; Paxeus 2004; Rúa-Gómez and Püttmann 2012). In this study, negligible concentrations of these drugs were detected in the effluents of the HWWTPs. These concentrations are lower than their respective PNECs of $1.38 \times 10^{4} \mathrm{ng} / \mathrm{L}$ for carbamazepine and $3.0 \times 10^{4} \mathrm{ng} / \mathrm{L}$ for atenolol (Verlicchi et al. 2012) and the PNEC of $1.06 \times 10^{5} \mathrm{ng} / \mathrm{L}$ for lidocaine as reported by AstraZeneca (2013). The concentrations of atenolol in effluent fall within the lower range of concentrations previously report for effluents of various MWWTPs in Saudi Arabia (15-2550 ng/L); however, carbamazepine in effluent was lower than levels previously reported (57-1200 ng/L) (Alidina et al. 2014).
Fig. 1 Schematic of the treatment processes employed in the a hospital wastewater treatment plant 1 and $\mathbf{b}$ hospital wastewater treatment plant 2 ; $(\mathrm{X}=$ sampling point $)$
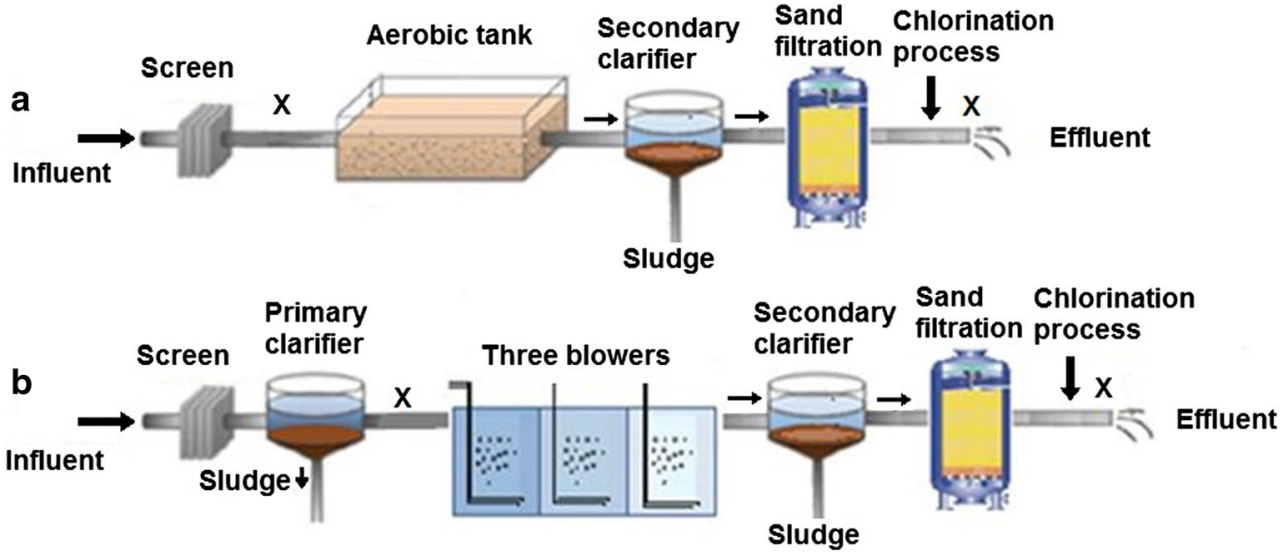
Table 3 Mass spectrometry: positive ion mode, range, and limit of quantification (LOQ)

\begin{tabular}{|c|c|c|c|c|c|}
\hline Analyte & MS ion/transition ${ }^{\mathrm{a}}$ & Retention time (min) & MS experiment & Linear range $(\mathrm{ng} / \mathrm{ml})$ & LOQ (ng/ml) \\
\hline Atenolol & 267.1703 & 6.38 & Full scan & $0.1-500$ & 5 \\
\hline Bezafibrate & $362.11-316.1089$ & 19.63 & Targeted MS2 & $0.1-500$ & 0.1 \\
\hline Carbamazepine & $237.10-194.0964$ & 17.72 & Targeted MS2 & $0.25-500$ & 0.25 \\
\hline Caffeine & 195.0877 & 7.20 & Full scan & $2.5-500$ & 2.5 \\
\hline Ciprofloxacin & $332.14-288.1505$ & 7.43 & Targeted MS2 & $0.25-500$ & 2.5 \\
\hline Clarithromycin & $748.48-158.1176$ & 19.08 & Targeted MS2 & $0.1-250$ & 0.5 \\
\hline Cyclophosphamide & $261.03-140.0029$ & 10.68 & Targeted MS2 & $0.5-500$ & 1 \\
\hline Erythromycin & $734.47-158.1176$ & 14.99 & Targeted MS2 & $0.5-500$ & 0.5 \\
\hline Lidocaine & 235.1805 & 7.88 & Full scan & $1-500$ & 1 \\
\hline NACS & $296.07-134.0602$ & 10.69 & Targeted MS2 & $2.5-500$ & 5 \\
\hline Paracetamol & 152.0706 & 6.80 & Full scan & $0.5-500$ & 0.5 \\
\hline Sulfamethoxazole & $254.06-108.0445$ & 10.59 & Targeted MS2 & $1-500$ & 1 \\
\hline
\end{tabular}

${ }^{\mathrm{a}}$ The underlined $\mathrm{m} / \mathrm{z}$ being used for quantification

\section{Potential influence of the operational parameters on removal efficiencies}

The removal efficiencies of pharmaceutical compounds from the hospital wastewater samples show that, on average, the highest decreases in effluent concentrations were observed for ciprofloxacin, caffeine, sulfamethoxazole, paracetamol, and NACS (>95\%), followed by atenolol, carbamazepine, and clarithromycin (>85\%). The average removal efficiency of lidocaine was greater than $65 \%$ at the two HWWTPs (Fig. 2).

\section{Paracetamol and caffeine}

Caffeine and paracetamol were both almost completely removed during treatment in each of the HWWTP. The average removal efficiency of paracetamol was $>98 \%$, while the caffeine was nearly completely ( $>99 \%$ ) removed by both HWWTPs. Similar results were obtained for the removal of paracetamol (up to $99 \%$ ) in AS processes by KasprzykHordern et al. (2009) and Verlicchi et al. (2013), under temperate climate conditions. Thus, paracetamol removal at WWTPs seems possible using conventional ASP under wider climate conditions (in both cold and warm weather). With regard to the removal of caffeine, Lin et al. (2010) reported similar caffeine removal efficiencies (99\%) in six Taiwanese WWTPs. In contrast to these results, Buerge et al. (2003) found that the removal efficiencies of caffeine varied (81$99 \%$ ) at 13 Swiss MWWTPs. The authors indicated that the MWWTPs that were less efficient at removing caffeine (81\%) employed lower adaptation times for the microorganisms in the AS system $(<5$ days versus $>5$ days). Bacterial adaptation in AS systems is enhanced through longer SRTs and higher temperatures (Batt et al. 2006). Therefore, in this study, the effective biodegradation of both compounds may have resulted from the high ambient temperatures and/or the possibility that both plants may have been operating with HRTs and SRTs that encouraged greater microbial adaptation.

\section{Antibiotics}

The mean removal efficiencies of ciprofloxacin, clarithromycin, sulfamethoxazole, and NACS were $>99,86$, $>98$, and $97 \%$, respectively. The HWWTP2 achieved almost complete removal of the antibiotics. Lin et al. (2009) previously studied sulfamethoxazole and clarithromycin and reported that the removal efficiencies of six different Taiwan WWTPs were greater than 50 and $20 \%$, respectively. Carballa et al. (2004) also found a lower removal efficiency $(<60 \%)$ of sulfamethoxazole in an AS plant located in temperate climate conditions (Galicia, Spain). A seasonal variation in the removal of sulfamethoxazole was observed, with a higher removal rate in summer (71 \%) than in winter (17\%), in Italy (Castiglioni et al. 2006). These results, and others listed in Table 1, are all much lower than the results observed in this study. Other studies observed the deconjugation of its metabolite (NACS), and thus higher concentrations of sulfamethoxazole in the effluent compared to the influent (Ashton et al. 2004; Göbel et al. 2007; Shelver et al. 2008). In this study, the high removal efficiencies of both sulfamethoxazole and NACS were observed under tropical climate conditions and no concentrations of sulfamethoxazole were detected in the effluent samples.

The other antibiotic (ciprofloxacin) was also completely removed ( $>99 \%$ ) in both HWWTPs. Gao et al. (2012) reported a lower removal efficiency (67\%) in a Chinese AS process. Ciprofloxacin is a fluoroquinolone and it is known that adsorption to sludge is a major removal process. For example, a significant amount of ciprofloxacin (up to $90 \%$ ) was removed 
Table 4 Concentrations of pharmaceutical compounds in hospital wastewater treatment plants in Saudi Arabia (ng/L) ${ }^{\mathrm{a}}$

\begin{tabular}{|c|c|c|c|c|c|c|}
\hline Class & Compound & $\mathrm{LOQ}^{\mathrm{b}}$ & $\begin{array}{l}\text { HWWTP1 } \\
\text { Inf. }\end{array}$ & $\begin{array}{l}\text { HWWTP1 } \\
\text { Eff. }\end{array}$ & $\begin{array}{l}\text { HWWTP2 } \\
\text { Inf. }\end{array}$ & $\begin{array}{l}\text { HWWTP2 } \\
\text { Eff. }\end{array}$ \\
\hline Analgesics & Paracetamol & 0.5 & $12400 \pm 340$ & $73 \pm 11$ & $12300 \pm 180$ & $157 \pm 20$ \\
\hline Antidepressants & Carbamazepine & 0.25 & $151 \pm 13$ & $41 \pm 1$ & $73 \pm 14$ & $\mathrm{n} / \mathrm{d}$ \\
\hline$\beta$-blockers & Atenolol & 5.0 & $730 \pm 82$ & $46 \pm 2$ & $329 \pm 28$ & $55 \pm 4$ \\
\hline Lipid regulators & Bezafibrate & 0.1 & $\mathrm{n} / \mathrm{d}$ & $\mathrm{n} / \mathrm{d}$ & $\mathrm{n} / \mathrm{d}$ & $\mathrm{n} / \mathrm{d}$ \\
\hline Anesthetics & Lidocaine & 1.0 & $158 \pm 12$ & $114 \pm 4$ & $129 \pm 6$ & $<\mathrm{LOQ}$ \\
\hline \multirow[t]{4}{*}{ Antibiotics } & Ciprofloxacin & 2.5 & $5600 \pm 660$ & $\mathrm{n} / \mathrm{d}$ & $2180 \pm 250$ & $\mathrm{n} / \mathrm{d}$ \\
\hline & Clarithromycin & 0.5 & $83 \pm 72$ & $22 \pm 9$ & 38 & $\mathrm{n} / \mathrm{d}$ \\
\hline & Sulfamethoxazole & 1.0 & $30 \pm 7$ & $\mathrm{n} / \mathrm{d}$ & $132 \pm 5$ & $\mathrm{n} / \mathrm{d}$ \\
\hline & Erythromycin & 0.5 & $\mathrm{n} / \mathrm{d}$ & $\mathrm{n} / \mathrm{d}$ & $\mathrm{n} / \mathrm{d}$ & $\mathrm{n} / \mathrm{d}$ \\
\hline Metabolite of sulfamethoxazole & NACS & 5.0 & $1200 \pm 55$ & $59 \pm 14$ & $506 \pm 21$ & $\mathrm{n} / \mathrm{d}$ \\
\hline Cytostatic & Cyclophosphamide & 1.0 & $\mathrm{n} / \mathrm{d}$ & $\mathrm{n} / \mathrm{d}$ & $\mathrm{n} / \mathrm{d}$ & $\mathrm{n} / \mathrm{d}$ \\
\hline Others & Caffeine & 2.5 & $74,800 \pm 15,500,502$ & $\mathrm{n} / \mathrm{d}$ & $27,500 \pm 2000$ & $\mathrm{n} / \mathrm{d}$ \\
\hline
\end{tabular}

$n / d$ not detected

${ }^{\text {a }}$ Each sample was analyzed in triplicate. Results are reported as mean $\pm \operatorname{standard~deviation}(n=3)$

${ }^{\mathrm{b}}$ Limit of quantitation (substances detected but not quantifiable); $n / d=$ not detected

via adsorption when the $\mathrm{pH}$ was less than 5.5 in a laboratory experiment (Githinji et al. 2011). However, adsorption has been observed to decrease with increasing temperatures (Seedher and Sidhu 2007) and an increase in $\mathrm{pH}(\mathrm{pH}>6)$ (Githinji et al. 2011). In this study, the removal efficiency of ciprofloxacin occurred under a high ambient temperature $\left(>26^{\circ} \mathrm{C}\right)$ and normal $\mathrm{pH}(7-8)$ conditions; this indicates that its removal was probably more as a result of biodegradation than adsorption.

\section{Carbamazepine}

The removal efficiency of carbamazepine by WWTPs has previously been found to be poor, mostly below $10 \%$ (Zhang et al. 2008). Removal rates from literature suggest consistently low removal rates across treatment types as shown in Table 1. In fact, increases in carbamazepine concentrations after wastewater treatment have been reported (Joss et al. 2005; Vieno et al. 2007). In the HWWTPs in Saudi Arabia in this study, a high average removal efficiency of carbamazepine $(>86 \%$ ) was observed. The HWWTP2 achieved $>99 \%$ removal of the compound. In Portugal, Dordio et al. (2010) reported similar removal efficiencies in wastewater collected in summer conditions ( $97 \%$ removal, average temperature $26^{\circ} \mathrm{C}$ ), but lower levels in wastewater collected in winter conditions ( $88 \%$ removal, average temperature $12{ }^{\circ} \mathrm{C}$ ), indicating an effect of temperature on biodegradation rates. In addition to temperature effects, solar degradation could play a major role in the removal of carbamazepine. Donner et al. (2013) found that after $120 \mathrm{~min}$ of UV treatment, the concentrations of carbamazepine in solution were decreased to approximately $1 \%$ of the starting concentration. High ambient temperatures and exposure to sunlight in Saudi Arabia may also have played a role in the high removal efficiencies observed for carbamazepine. These findings were unexpected; they suggest that conventional WWTPs could remove carbamazepine under certain conditions and that tropical climate conditions are potentially more favorable than temperate ones.

\section{Atenolol}

The average removal efficiency of atenolol by the HWWTPs was $89 \%$. The removal efficiencies of this compound reported in the literature vary drastically from study to study. For example, in WWTPs located in temperate climates (in Europe), Paxeus (2004) reported a removal efficiency of $<10 \%$, while Vieno et al. (2005) reported a removal efficiency of $61 \%$. Castiglioni et al. (2006) found that the removal efficiency of atenolol was affected by temperature, where higher removal efficiencies were achieved in summer $(55 \%)$ than in winter $(10 \%)$. This indicates that the high removal efficiencies achieved by the HWWTPs in Saudi Arabia observed in this study could be due to higher microbial activity in the tropical climate.

\section{Lidocaine}

The average removal efficiency of lidocaine by the HWWTPs was $64 \%$; however, the difference between removal at HWWTP1 and HWWTP2 was large with 28 and $>99 \%$ removal observed respectively. The removal efficiency of lidocaine was assessed at various WWTPs in a temperate climate (Hesse, Germany), where it was found to be significantly 
Fig. 2 Removal efficiencies of pharmaceutical compounds at HWWTP1 and HWWPT2 in Saudi Arabia. Results shown are mean removal $(n=3)$

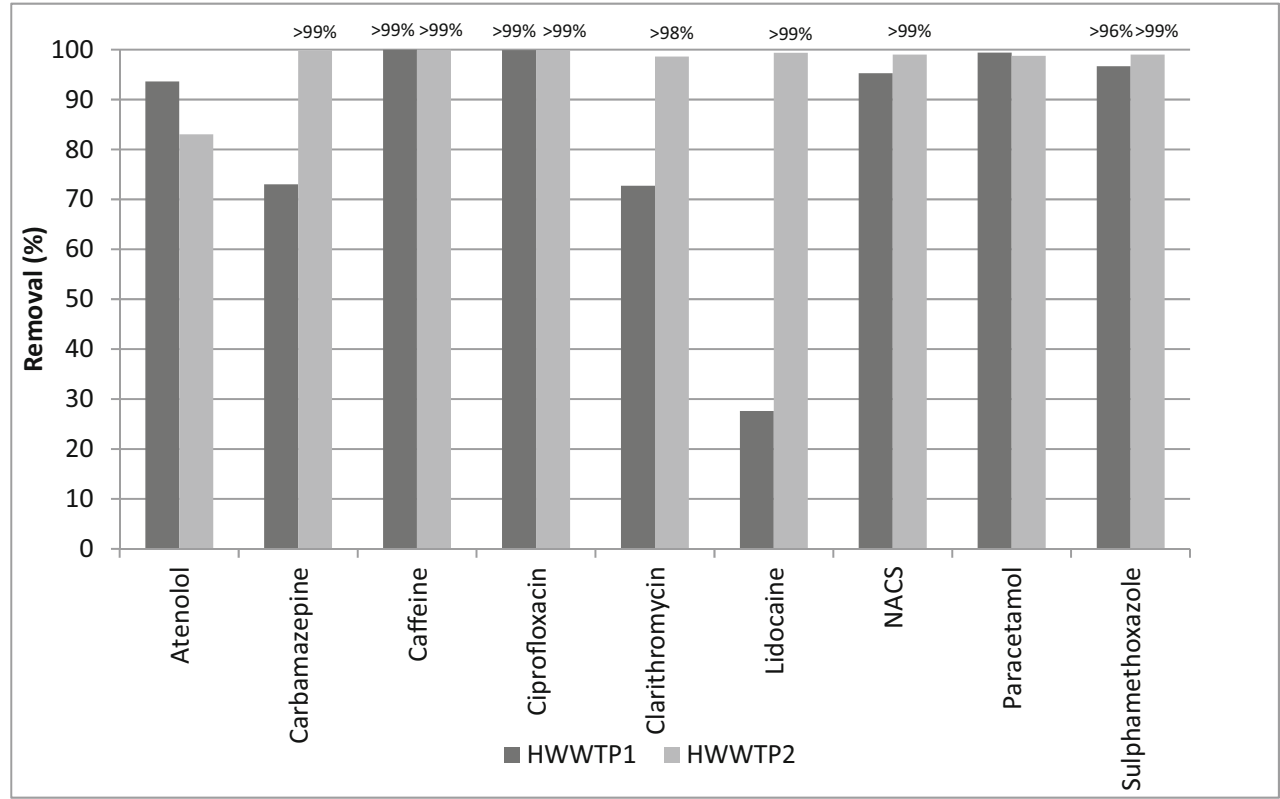

lower (10-50 \%) (Rúa-Gómez and Püttmann 2012) than that observed in this study. Kovalova et al. (2012) also found only moderate removal of lidocaine in a pilot-scale MBR treating hospital wastewater.

\section{Discussion of the importance of key factors on removal efficiency}

The removal efficiencies of selected pharmaceutical compounds measured in this study appeared to be much improved in the hotter, tropical climate of Saudi Arabia.

Other studies have found that higher removal efficiencies are observed during the summer in temperate climates, by an average of $25 \%$, compared to winter (Vieno et al. 2005). In another study, which examined six large WWTPs in Italy, Castiglioni et al. (2006) also found higher removal efficiencies in summer $\left(18.6{ }^{\circ} \mathrm{C}\right)$ than in winter $\left(9.7^{\circ} \mathrm{C}\right)$, except for the removal efficiencies of carbamazepine and ciprofloxacin, which were similar across the two seasons. In this study, >99\% removal efficiencies in relation to ciprofloxacin at both HWWTP and carbamazepine at HWWTP2 were achieved. In addition, very high removal efficiencies regarding the antibiotics, atenolol, and lidocaine were achieved; these compounds are normally found to be persistent in conventional WWTPs in temperate climates (Paxeus 2004; Rúa-Gómez and Püttmann 2012; Carballa et al. 2004). Thus, the higher ambient temperatures $\left(>26{ }^{\circ} \mathrm{C}\right.$ ), which are present almost year-round in the tropical Saudi Arabian climate, may have enhanced the removal efficiencies of these compounds. This is because the tropical conditions may have led to a high level of microbial activity during the AS process, which may, in turn, have increased the biodegradation kinetics. This theory is supported by the knowledge that microorganisms living in reactors at WWTPs usually reach their optimal activity rates at warm temperatures, $25-35{ }^{\circ} \mathrm{C}$ (Cruikshank and Gilles 2007; Kareem 2013).

Other factors, such as sunlight availability (which is important for photodegradation), may also have influenced the removal efficiency of the pharmaceutical compounds (Kasprzyk-Hordern et al. 2009), particularly carbamazepine (Donner et al. 2013). It should be noted, however, that removal from effluent does not necessarily result in reduced toxicity. In the experiments by Donner et al. (2013), UV exposure was found to coincide with both a decrease in carbamazepine, but also an initial increase in degradation products acridine and acridone, which were shown to be significantly more toxic in acute toxicity assays than carbamazepine. More comprehensive studies are needed to investigate the multiple factors that cause parent compound degradation, but potential formation of recalcitrant degradation byproducts, and the relative toxicity.

In addition, the HWWTPs assessed in this study applied tertiary treatments, in the forms of sand filtration and disinfection. It is possible that sand filtration had an effect on the removal efficiencies of the pharmaceutical compounds. However, the removal of pharmaceutical compounds during sand filtration has generally been reported to be inefficient (Hollender et al. 2009; Nakada et al. 2007; Lin et al. 2010; Kosma et al. 2010). Therefore, in this study, although the samples were collected after the final treatment, in the interpretation of the results, it has been assumed that sand filtration played negligible roles in the fate of the target micropollutants in the plants. However, the contribution of the tertiary 
treatments to the removal of the pharmaceutical compounds requires investigation.

The role of chlorination may also be significant for some compounds. Removal of antibiotics, including sulfamethoxazole and ciprofloxacin (Li and Zhang 2012; Dodd et al. 2005), endocrine disrupting compounds and anti-inflammatory drugs (Noutsopoulos et al. 2015) have been shown to be affected by chlorination, with $\mathrm{pH}$ influencing the level of removal achieved. For acidic pharmaceuticals, some compounds have been found to degrade significantly due to chlorination (salicylic acid, naproxen, diclofenac, indomethacin); however, chlorine does not seem to lead to degradation of others (bezafibrate, ketoprofen, ibuprofen) (Quintana et al. 2010).

Finally, only the liquid wastewater was tested in this study and it is possible that the pollutants were adsorbed onto the sludge. It is noted that some substances will be more prevalent to sorption to sludges than others. Carbamazepine for example displays extremely low sorption to sludges, and sulfamethoxazole shows low sorption therefore removal by sorption to sludge is unlikely to be a primary removal mechanism for these compounds, whereas atenolol displays moderate sorption therefore some removal may be due to sorption (Horsing et al. 2011). This is an area for further study and investigation in tropical climates.

\section{Conclusions}

The onsite HWWTPs in Saudi Arabia achieved high removal efficiencies from wastewater of the pharmaceutical compounds tested, including ciprofloxacin, clarithromycin, sulfamethoxazole and NACS, paracetamol, caffeine, atenolol, lidocaine, and carbamazepine, from the wastewater. The high removal efficiencies of carbamazepine, in particular, were unexpected due to the recalcitrant nature of this compound. Temperature, and potentially photodegradation, were identified to be factors that probably led to the high removal efficiencies achieved. More work is needed to confirm the role that these, and other potential factors, play.

Acknowledgments The authors wish to acknowledge the Saudi Government (Ministry of Health) for graciously funding this study. The authors also acknowledge Joanne Roberts and Dr. Moyra McNaughton at Glasgow Caledonian University, United Kingdom, for their assistance in carrying out the analysis of pharmaceutical substances.

\section{Compliance with ethical standards}

Funding The study was funded by the Ministry of Health of the Saudi Government.

Conflict of interest The authors declare that they have no conflict of interest.
Open Access This article is distributed under the terms of the Creative Commons Attribution 4.0 International License (http:// creativecommons.org/licenses/by/4.0/), which permits unrestricted use, distribution, and reproduction in any medium, provided you give appropriate credit to the original author(s) and the source, provide a link to the Creative Commons license, and indicate if changes were made.

\section{References}

Aksakal A, Rehman S (1999) Global solar radiation in Northeastern Saudi Arabia. Renew Energy 17:461-472

Alder A, Bruchest A, Carballa M, Clara M, Joss A, Loffler D, McArdell C, Miksck K, Omil F, Tukhanen T, Ternes T (2006) "Consumption and occurrence". In: Ternes T, Joss A (eds) Human pharmaceuticals hormones and fragrances, the challenge of micropollutants in urban water management. IWA Publishing, London

Alidina M, Hoppe-Jones C, Yoon M, Hamadeh AF, Li D, Drewes JE (2014) The occurrence of emerging trace organic chemicals in wastewater effluents in Saudi Arabia. Sci Total Environ 478: $152-162$

Almazroui M, Islam MN, Dambul R, Jones PD (2014) Trends of temperature extremes in Saudi Arabia. Int J Climatol 34:808-826

Arévalo J, Ruiz LM, Pérez J, Gómez MA (2014) Effect of temperature on membrane bioreactor performance working with high hydraulic and sludge retention time. Biochem Eng J 88:42-49

Ashton D, Hilton M, Thomas KV (2004) Investigating the environmental transport of human pharmaceuticals to streams in the United Kingdom. Sci Total Environ 333:167-184

AstraZeneca (2013) Environmental risk assessment data: lidocaine hydrochloride monohydrate. Available at: https://www.astrazeneca. com/content/dam/az/our-company/Sustainability/LidocaineHydrochloride-Monohydrate.pdf

Batt AL, Kim S, Aga DS (2006) Enhanced biodegradation of iopromide and trimethoprim in nitrifying activated sludge. Environ Sci Technol 40:7367-7373

Buerge IJ, Poiger T, Müller MD, Buser H (2003) Caffeine, an anthropogenic marker for wastewater contamination of surface waters. Environ Sci Technol 37:691-700

Calderón K, González-Martínez A, Montero-Puente C, Reboleiro-Rivas P, Poyatos JM, Juarez-Jiménez B, Martínez-Toledo MV, Rodelas B (2012) Bacterial community structure and enzyme activities in membrane bioreactor (MBR) using pure oxygen as an aeration source. Bioresour Technol 103:87-94

Carballa M, Omil F, Lema JM, Llompart M, Garcia-Jares C, Rodriguez I, Gomez M, Ternes T (2004) Behavior of pharmaceuticals, cosmetics and hormones in a sewage treatment plant. Water Res 38:2918-2926

Carballa M, Omil F, Ternes T, Lema JM (2007) Fate of pharmaceutical and personal care products (PPCPs) during anaerobic digestion of sewage sludge. Water Res 41(10):2139-2150

Castiglioni S, Bagnati R, Fanelli R, Pomati F, Calamari D, Zuccato E (2006) Removal of pharmaceuticals in sewage treatment plants in Italy. Environ Sci Technol 40:357-363

Chen ZB, He ZW, Tang CC, Hu DX, Cui YB, Wang AJ, Zhang Y, Yan LL, Ren NQ (2014) Performance and model of a novel multi-sparger multi-stage airlift loop membrane bioreactor to treat high-strength 7-ACA pharmaceutical wastewater: effect of hydraulic retention time, temperature and $\mathrm{pH}$. Bioresour Technol 167:241-250

Clara M, Strenn B, Gans O, Martinez E, Kreuzinger N, Kroiss H (2005) Removal of selected pharmaceuticals, fragrances and endocrine disrupting compounds in a membrane bioreactor and conventional wastewater treatment plants. Water Res 39(19):4797-4807 
Cruikshank CL, Gilles DG (2007) Temperature modeling and control for biological wastewater treatment design. Proc Water Environ Fed Ind Water Qual 120-132(13)

Dodd MC, Shah AD, Von-Gunten U, Huang CH (2005) Interactions of fluoroquinolone antibacterial agents with aqueous chlorine: reaction kinetics, mechanisms, and transformation pathways. Environ Sci Technol 39(18):7065-7076

Donner E, Kosjek T, Qualmann S, Kusk KO, Heath E, Revitt DM, Ledin A, Andersen HR (2013) Ecotoxicity of carbamazepine and its UV photolysis transformation products. Sci Total Environ 443:870-876

Dordio A, Carvalho AJP, Teixeira DM, Dias CB, Pinto AP (2010) Removal of pharmaceuticals in microcosm constructed wetlands using Typha spp. and LECA. Bioresour Technol 101:886-892

Escola Casas M, Chhetri RK, Ooi G, Hansen KMS, Litty K, Christensson M, Kragelund C, Andersen HR, Bester K (2015) Biodegradation of pharmaceuticals in hospital wastewater by staged moving bed biofilm reactors MBBR). Water Res 83:293-302

Fernandez-Fontaina E, Omil F, Lema JM, Carballa M (2012) Influence of nitrifying conditions on the biodegradation and sorption of emerging micropollutants. Water Res 46:5434-5444

Gao P, Ding Y, Li H, Xagoraraki I (2012) Occurrence of pharmaceuticals in a municipal wastewater treatment plant: mass balance and removal processes. Chemosphere 88(1):17-24

Githinji LJM, Musey MK, Ankumah RO (2011) Evaluation of the fate of ciprofloxacin and amoxicillin in domestic wastewater. Water Air Soil Pollut 219:191-201

Göbel A, McArdell CS, Joss A, Siegrist H, Giger W (2007) Fate of sulfonamides, macrolides, and trimethoprim in different wastewater treatment technologies. Sci Total Environ 372:361-371

Hai FI, Tessmer K, Nguyen LN, Kang J, Price WE, Nghiem LD (2011) Removal of micropollutants by membrane bioreactor under temperature variation. J Membr Sci 383:144-151

Heberer T (2002) Occurrence, fate, and removal of pharmaceutical residues in the aquatic environment: a review of recent research data. Toxicol Lett 131:5-17

Helwig K, Hunter C, MacLachlan J, McNaughtan M, Roberts J, Cornelissen A, Pahl O (2013) Micropollutant point sources in the built environment: identification and monitoring of priority pharmaceutical substances in hospital effluents. J Environ Anal Toxicol 3(4): $1-10$

Hollender J, Zimmermann SG, Koepke S, Krauss M, McArdell CS, Ort C, Singer H, von Gunten U, Siegrist H (2009) Elimination of organic micropollutants in a municipal wastewater treatment plant upgraded with a full-scale post-ozonation followed by sand filtration. Environ Sci Technol 43:7862-7869

Horsing M, Ledin A, Grabic R, Fick J, Tysklind M, Jansen JLC, Andersen H (2011) Determination of sorption of seventy-five pharmaceuticals in sewage sludge. Water Res 45:4470-4482

Joss A, Keller E, Alder AC, Göbel A, McArdell CS, Ternes T, Siegrist H (2005) Removal of pharmaceuticals and fragrances in biological wastewater treatment. Water Res 39:3139-3152

Kareem MBA (2013) Biotreatment of Al-Yarmouk hospital wastewater using packed bed bioreactor. Iraqi J Biotechnol 12:91-100

Kasprzyk-Hordern B, Dinsdale RM, Guwy AJ (2009) The removal of pharmaceuticals, personal care products, endocrine disruptors and illicit drugs during wastewater treatment and its impact on the quality of receiving waters. Water Res 43:363-380

Kim M, Guerra P, Shah A, Parsa M, Alaee M, Smyth S (2014) Pharmaceuticals and personal care products removal in a membrane bioreactor wastewater treatment plant. Water Sci Technol 69(11): 2221-2229

Kolpin DW, Furlong ET, Meyer MT, Thurman EM, Zaugg SD, Barber LB, Buxton HT (2002) Pharmaceuticals, hormones, and other organic wastewater contaminants in US streams, 1999-2000: a national reconnaissance. Environ Sci Technol 36:1202-1211
Kosma CI, Lambropoulou DA, Albanis TA (2010) Occurrence and removal of PPCPs in municipal and hospital wastewaters in Greece. J Hazard Mater 179(1-3):804-817

Kovalova L, Siegrist H, Singer H, Wittmer A, McArdell C (2012) Hospital wastewater treatment by membrane bioreactor: performance and efficiency for organic micropollutant elimination. Environ Sci Technol 46(3):1536-1545

Kümmerer K (2009) Antibiotics in the aquatic environment — a reviewpart I. Chemosphere 75:417-434

LaPara TM, Konopka A, Nakatsu CH, Alleman JE (2000) Effects of elevated temperature on bacterial community structure and function in bioreactors treating a synthetic wastewater. J Ind Microbiol Biotechnol 24:140-145

Li B, Zhang T (2012) pH significantly affects removal of trace antibiotics in chlorination of municipal wastewater. Water Res 46(11):3703-3713

Li X, Zheng W, Kelly WR (2013) Occurrence and removal of pharmaceutical and hormone contaminants in rural wastewater treatment lagoons. Sci Total Environ 445-446:22-28

Lin AY, Yu TH, Lateef SK (2009) Removal of pharmaceuticals in secondary wastewater treatment processes in Taiwan. J Hazard Mater 167:1163-1169

Lin AY, Lin CF, Tsai YT, Lin HH, Chen J, Wang XH, Yu TH (2010) Fate of selected pharmaceuticals and personal care products after secondary wastewater treatment processes in Taiwan. Water Sci Technol 62:2450-2458

Martín J, Camacho-Munoz D, Santos JL, Aparicio I, Alonso E (2012) Occurrence of pharmaceutical compounds in wastewater and sludge from wastewater treatment plants: removal and ecotoxicological impact of wastewater discharges and sludge disposal. J Hazard Mater 239-240:40-47

Massmann G, Greskowiak J, Dünnbier U, Zuehlke S, Knappe A, Pekdeger A (2006) The impact of variable temperatures on the redox conditions and the behaviour of pharmaceutical residues during artificial recharge. J Hydrol 328:141-156

McAdam EJ, Bagnall JP, Koh YK, Chiu TY, Pollard S, Scrimshaw MD, Lester JN, Cartmell E (2010) Removal of steroid estrogens in carbonaceous and nitrifying activated sludge processes. Chemosphere $81: 1-6$

Metcalfe CD, Miao XS, Koenig BG, Struger J (2003) Distribution of acidic and neutral drugs in surface water near sewage treatment plants in the lower Great Lakes, Canada. Environ Toxicol Chem 22:2881-2889

Miao XS, Yang JJ, Metcalfe CD (2005) Carbamazepine and its metabolites in wastewater and in biosolids in a municipal wastewater treatment plant. Environ Sci Technol 39:7469-7475

Monteiro SC, Boxall ABA (2010) Occurrence and fate of human pharmaceuticals in the environment. Rev Environ Contam Toxicol 202:53-154

Musson SE, Campo P, Tolaymat T, Suidan M, Townsend TG (2010) Assessment of the anaerobic degradation of six active pharmaceutical ingredients. Sci Total Environ 408(9):2068-2074

Nakada N, Shinohara H, Murata A, Kiri K, Managaki S, Sato N, Takada H (2007) Removal of selected pharmaceuticals and personal care products (PPCPs) and endocrine-disrupting chemicals (EDCs) during sand filtration and ozonation at a municipal sewage treatment plant. Water Res 41:4373-4382

Nielsen U, Hastrup C, Klausen MM, Pedersen BM, Kristensen GH, Jansen JLC, Bak SN, Tuerk J (2013) Removal of APIs and bacteria from hospital wastewater by MBR plus $\mathrm{O} 3, \mathrm{O} 3+\mathrm{H} 2 \mathrm{O} 2, \mathrm{PAC}$ or ClO2. Water Sci Technol 67(4):854-862

Noutsopoulos C, Koumaki E, Mamais D, Nika MC, Bletsou AA, Thomaidis NS (2015) Removal of endocrine disruptors and nonsteroidal anti-inflammatory drugs through wastewater chlorination: the effect of $\mathrm{pH}$, total suspended solids and humic acids and identification of degradation by-products. Chemosphere 119(1):109-114 
Ohlsen K, Ternes T, Werner G, Wallner U, Löffler D, Ziebuhr W, Hacker $\mathrm{J}$ (2003) Impact of antibiotics on conjugational resistance gene transfer in staphylococcus aureus in sewage. Environ Microbiol 5(8): $711-716$

Oppenheimer J, Stephenson R, Burbano A, Liu L (2007) Characterizing the passage of personal care products through wastewater treatment processes. Water Environ Res 79(13):2564-2577

Ort C, Lawrence M, Reungoat J, Mueller J (2010) Sampling for PPCPs in wastewater systems: comparison of different sampling modes and optimization strategies. Environ Sci Technol 44(16):6289-6296

Paxeus N (2004) Removal of selected non-steroidal anti-inflammatory drugs (NSAIDs), gemfibrozil, carbamazepine, beta-blockers, trimethoprim and triclosan in conventional wastewater treatment plants in five EU countries and their discharge to the aquatic environment. Water Sci Technol 50:253-260

Phillips PJ, Smith SG, Kolpin DW, Zaugg SD, Buxton HT, Furlong ET, Esposito K, Stinson B (2010) Pharmaceutical formulation facilities as sources of opioids and other pharmaceuticals to wastewater treatment plant effluents. Environ Sci Technol 44:4910-4916

Pollice A, Tandoi V, Lestingi C (2002) Influence of aeration and sludge retention time on ammonium oxidation to nitrite and nitrate. Water Res 36:2541-2546

Qadir M, Bahri A, Sato T, Al-Karadsheh E (2010) Wastewater production, treatment, and irrigation in Middle East and North Africa. Irrig Drain Syst 24:37-51

Quintana JB, Rodil R, Lopez-Mahia P, Muniategui-Lorenzo S, PradaRodriguez D (2010) Investigating the chlorination of acidic pharmaceuticals and by-product formation aided by an experimental design methodology. Water Res 44(1):243-255

Radjenović J, Petrović M, Barceló D (2009) Fate and distribution of pharmaceuticals in wastewater and sewage sludge of the conventional activated sludge (CAS) and advanced membrane bioreactor (MBR) treatment. Water Res 43(3):831-841

Rúa-Gómez PC, Püttmann W (2012) Occurrence and removal of lidocaine, tramadol, venlafaxine, and their metabolites in German wastewater treatment plants. Environ Sci Pollut Res 19:689-699

Sahar E, Messalem R, Cikurel H, Aharoni A, Brenner A, Godehardt M, Jekel M, Ernst M (2011) Fate of antibiotics in activated sludge followed by ultrafiltration (CAS-UF) and in a membrane bioreactor (MBR). Water Res 45:4827-4836

Schaider LA, Rudel RA, Ackerman JM, Dunagan SC, Brody JG (2014) Pharmaceuticals, perfluorosurfactants, and other organic wastewater compounds in public drinking water wells in a shallow sand and gravel aquifer. Sci Total Environ 468-469:384-393

Seedher N, Sidhu K (2007) Studies on the use of tea leaves as pharmaceutical adsorbent. Int J Biol Chem 1:162-167
Shelver WL, Shappell NW, Franek M, Rubio FR (2008) ELISA for sulfonamides and its application for screening in water contamination. J Agric Food Chem 56:6609-6615

Shraim A, Diab A, Alsuhaimi A, Niazy E, Metwally M, Amad M, Sioud S, Dawoud A (2012) Analysis of some pharmaceuticals in municipal wastewater of Almadinah Almunawarah. Arab J Chem. doi:10. 1016/j.arabjc.2012.11.014

Sui Q, Huang J, Deng S, Yu G, Fan Q (2010) Occurrence and removal of pharmaceuticals, caffeine and DEET in wastewater treatment plants of Beijing, China. Water Res 44:417-426

Tewari S, Jindal R, Kho YL, Eo S, Choi K (2013) Major pharmaceutical residues in wastewater treatment plants and receiving waters in Bangkok, Thailand, and associated ecological risks. Chemosphere 91:697-704

Verlicchi P, Galletti A, Masotti L (2010) Management of hospital wastewaters: the case of the effluent of a large hospital situated in a small town. Water Sci Technol 61(10):2507-2519

Verlicchi P, Al Aukidy M, Zambello E (2012) Occurrence of pharmaceutical compounds in urban wastewater: removal, mass load and environmental risk after a secondary treatment - a review. Sci Total Environ 429:123-155

Verlicchi P, Galletti A, Petrovic M, Barceló D, Al Aukidy M, Zambello E (2013) Removal of selected pharmaceuticals from domestic wastewater in an activated sludge system followed by a horizontal subsurface flow bed - analysis of their respective contributions. Sci Total Environ 454-455:411-425

Vieno NM, Tuhkanen T, Kronberg L (2005) Seasonal variation in the occurrence of pharmaceuticals in effluents from a sewage treatment plant and in the recipient water. Environ Sci Technol 39: $8220-8226$

Vieno N, Tuhkanen T, Kronberg L (2007) Elimination of pharmaceuticals in sewage treatment plants in Finland. Water Res 41:1001-1012

Vulliet E, Cren-Olivé C, Grenier-Loustalot MF (2011) Occurrence of pharmaceuticals and hormones in drinking water treated from surface waters. Environ Chem Lett 9:103-114

Weigel S, Kuhlmann J, Hühnerfuss H (2002) Drugs and personal care products as ubiquitous pollutants: occurrence and distribution of clofibric acid, caffeine and DEET in the North Sea. Sci Total Environ 295:131-141

Yu JT, Bouwer EJ, Coelhan M (2006) Occurrence and biodegradability studies of selected pharmaceuticals and personal care products in sewage effluent. Agric Water Manag 86:72-80

Zhang Y, Geiben S, Gal C (2008) Carbamazepine and diclofenac: removal in wastewater treatment plants and occurrence in water bodies. Chemosphere 73:1151-1161 